\title{
Reflexivity of Worship as Salat by God to be Multinaturalism and Religion based on Hahsım
}

\author{
Roikhan Mochamad Aziz \\ \{roikhan.ma@uinjkt.ac.id\} \\ Universitas Islam Negeri Syarif Hidayatullah, Indonesia
}

\begin{abstract}
The study aims to analyze the reflexivity of religion on worship as the basic design of the multinaturalism in-universe by god as the creator with a benchmark of Hahslm approach. Religiosity connects to multiculturalism with the ontology of worship based on the Holy Book. The relation among ibadah, God, and the universe make a system in the epistemology concept. Object research is a religion that is defined as worship with the universe as a projection of ibadah. Multinaturalism is drawn by numbers and interpretation of 19. God is 1 and worship is 9. The appearance of nineteen can be found in multinaturalism such as the human body, prime numbers, plant, and animal. The study used a qualitative descriptive approach from the Holy Book, literature review, journals, books, and internet media. The hypotheses of this research are multicultural and multinaturalism have something in common, then there must be a basic design about this common pattern. And also, the pattern of humans and other creations has in common pattern then there must be a basic design for this similarity. This research uses methodologies such as triangulation of 19, reflexivity of source creator creation, and Hahslm thinking of digital numbers 472319 with 3 variables of worship God-human. Studies have shown that God has the first creation of salat, with this worship as a basic design the God creates the universe in multiculturalism and multinaturalism. Multiculturalism and multinaturalism have the same origin of the design, that is worship. This conclusion is accurately the same as the phrases in the Holy Book that God made a basic design to create the universe. And also, these phrases are consistent with the logical thinking of humans that before someone builds a thing, humanmade a design first.
\end{abstract}

Keywords: Reflexivity, Salat, Hahslm, 19, The Universe

\section{Introduction}

The whole science that scientists and academics are searching for a new base as a secure place to get back to the leaps of science. Then came the questions to address the above problems in the form of puzzles [1], the need for a new ontology that could connect the human desire to reach the top of science with the availability of data and knowledge.

There is also an approach that combines with the various disciplines of multidiscipline. There is also an approach that combines with different disciplines called inter-discipline [2]. Its development has also reflected a reflexive approach that approaches the basic theory of ontology. Reflexivity is a reflection of the blueprint that radiates in existing science and natural phenomena.

The problem of the study of Islam and this knowledge is:

a. It takes ontology from the merging of worship and multinaturalism 
b. Analyzing religion and science of the reflections of salat.

The broad creation of all science is designed by salat as an ontological view. The introduction of all these ibadah ideas is the beginning of the entire life system. Before God had created the universe, the creator set up the design of worship [3]. All creations by God could be reflected as the ibadah.

The relation among salat, God, and human is an epistemological view. Islam can be seen as a philosophy with a systematic approach, a detailed view, and a Kaffah viewpoint. Then Islam, as a method, is the origin of the idea of incorporation into science and philosophy [4].

There are many approaches about integration to combine 2 entities (religion and nature) into 1 entity as knowledge, such as interconnected, multidisciplinary, interdisciplinary, transdisciplinary. And this study also has a reflexivity approach that is grouped in an ontological perspective with Hahslm as a formula. Those approaches are grouped in epistemological perspectives.

\section{Theory}

There are some theories about integration. The theory of Hahlsm according to Aziz [5] is defined as a theory of three dominant archetypes with a specific context in five dimensions of invariant arrangement. These make up 3 figures of 1 as a symbol of God, 9 as a symbol of prayer, and 3 as symbols of human Numbers. Three Numbers in the mathematical theory of triangulation to 3.1 .9 or 9.1.3, which places the number 1 at the center, between 3 and 9. From Numbers theory, transformations to reflective methods. This theory is a symbolic reflection approach, which can come in terms of figures, text shapes, and picture shapes, as well as other shapes. The elements arising are salat, god, and man. The salat element in this reflexive method is a design, blueprint, or archetype. The element of god becomes the mirror or projector as a creator. And the human element became a symbol of a person standing in front of a mirror, an or a symbol of a projection picture, or a symbol of a suit. A system, according to Islam has at least three elements. Kaffah thinking is a system of three or more interrelated elements. The elements of thinking are embodied in the entities (subject and object), and the entering (worship). The causation of thinking is the three elements are' full variable 'not just the genre or direction [6].

Science of Everything based on the above 3 paradigms of science theory. First, ontology has made worship the fundamental concept. Second, Islam is an epistemology that reflected the importance of science. Third, axiology conducted system disciplinary.

In the early days of human civilization, god passed down his science to the prophets, it was called the science of god [7]. This knowledge of God is meant to the divinely given knowledge of prophets, including the study of God. This science of god combines with religious science. Then by western scientists, this science from god was relegated to science. And now, with the Covid-19 pandemic, researchers are beginning to catalyze the integration of religious science with science. This transition into merging the two approaches is filled with an approach that combines 2 sets of sciences into one system with a theme of Islam and knowledge or religion and science [8]. This approach combines 2 subsystems into one large system. There is still a differentiation presented in one container. 


\section{Methodology}

\subsection{Type of Research}

Type of research is descriptive by analyzing, describing, defining, describing, or explaining the reflexivity regarding integration between Islam and science [9]. This research was conducted with literary studies looking for theoretical references relevant to triangular mathematics, kaffah thinking, and reflexivity.

\subsection{Research Scope}

The scope of the research is about science, Islam, reflexivity, and Mathematics.

\subsection{Data Collection Methods}

This research uses secondary data obtained through intermediary media. This data can be obtained through books, notes, existing evidence, or published articles and journals for reference [10].

\subsection{Hahslm Methodology}

This study uses the Hahslm methodology by incorporating the value of worship into data processing. Qualitatively. In the Hahslm methodology, the meaning is that kauniyah is the same as qauliyah.

The life system that exists in humans, in the environment, and the universe originates from the concept of Islam, in other words, the concept of early creation is Islam. The word Islam has a root word of three letters, namely the letter 's' or sin, the letter ' $\mathrm{l}$ ' or lam, and the letter ' $\mathrm{m}$ ' or $\mathrm{mim}$. There is a verse that supports the ontological meaning of Islam.

\subsection{Analysis}

Islamization and inequality in reflexization have differentiation on its basic philosophy. Islamization and inequality are richer by epistemology. Whereas reflexivity is a concept reflected in ontology. These reflexes can be seen from the number of letter Numbers, verse Numbers (51.56) which is $5+1+5+6=17$. The number of obligatory prayers is 17 degrees. In this reflexive method of the creation verse the number 19 (one nine).

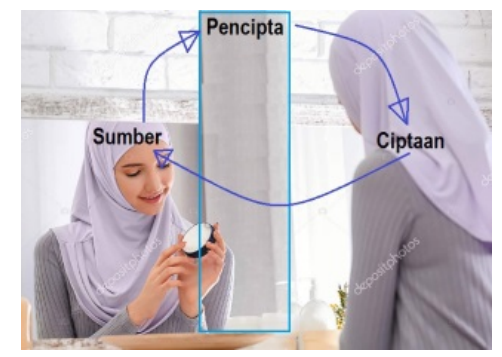

Fig. 1. Reflexivity of Source Creator-Creation (Analysis, 2020). 
The reflexivity diagram above consists of the 3 elements that are, the source, the creator, the creation. These three basic elements are converted into reflections of shadow, mirrors, and mirror people. Sources are transformed into shadows, the creator is transformed into mirrors, and creation is incorporated into the mirror. In the process of creation, these three elements are a common thread from sources, creator $=$ god, creation $=$ man, then conversion of salutes $=$ shadow, god $=$ mirror, man $=$ mirror. A system consisting of a 9.1.3 in kaffah's method of thinking suggests that a system that starts from 1 to 3 , then to 9 . When a 9 goes to a 1 , a 9 goes first in the system. It originally meant god created humans for worship [11]. Could be: worship flexibly god forms human.

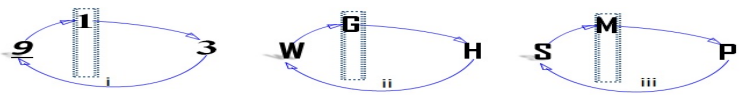

Fig. 2. Kaffah Thinking (Analysis, 2020).

Information:

Source: 9 or Worship (W) or Shadow (S).

Creator: 1 or God (G) or Mirror (M).

Creation: 3 or Human (H) or People (P).

The kaffah thinking diagram above says that the source of the human reflector is worship, of which is god himself. So, this existing human body is reflexive of worship. The existence of a human body structure is a transformation of the worship symbol. In the kaffah thinking diagram, an easy picture is $\mathrm{s}, \mathrm{m}, \mathrm{p}$. S stands for shadow, $\mathrm{m}$ stands for the mirror, and $\mathrm{p}$ stands for people. The reflection in the mirror is reflected onto the people or can be read as well as people have a shadow behind the mirror [12].

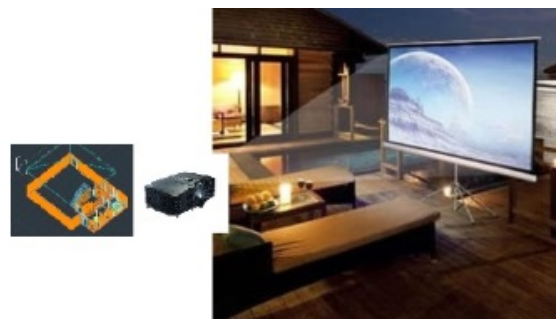

Fig. 3. Reflexivity Design of Ibadah (Analysis, 2020).

The reflexivity diagram shows that this third variable exists which is an interpretation of worship. The meaning of the 3rd variable becomes consistent between the existence of the creation verse and the projector function [6]. The existence of a projector is a creator's function that creates a building from the reflexivity and design of an architect's house. So, humans who were created by God came from prayer as the source. 


\section{Conclusion}

The fundamental of Islam and science with integration is worship. Worship is the source of the pattern of human creation. Humans were created with the value of worship, so the application of true academic and industry values also provides the value of worship. Islamization and integration run simultaneously with reflexivity, with an emphasis on the use of religious value in science.

Reflexivity has 3 elements that are transformed as a shadow, mirror, and human to other entities and intangible elements. Elements of source, creator, and creation can be transformed into salat, God, and universe where Islamization and Integration can be blended in a basic design. The basic design of the universe is salat that is reflected by God as the universe.

\section{References}

[1] A. Ikhwan, "Perguruan Tinggi Islam dan Integrasi Keilmuan Islam," At-Tajdid J. Ilmu Tarb., vol. 5, no. 2, pp. 159-187, 2016.

[2] M. Iqbal, Contemporary Issues in Islam and Science: Volume 2. Routledge, 2017.

[3] M. Mukharom and H. Aravik, "Kebijakan Nabi Muhammad Saw Menangani Wabah Penyakit Menular dan Implementasinya dalam Konteks Penanggulangan Coronavirus Covid-19," SALAM J. Sos. dan Budaya Syar-i, vol. 7, no. 3, pp. 239-246, 2020.

[4] M. Munadi, "Integration of Islam and Science: Study of Two Science Pesantrens (Trensain) in Jombang and Sragen," J. Pendidik. Islam, vol. 5, no. 2, pp. 287-303, 2016.

[5] R. M. Aziz, "Teori H Sebagai Ilmu Wahyu Dan Turats Dalam Islam,” J. Ushuluddin, vol. 24, no. 1, pp. 103-112, 2016.

[6] R. M. Aziz, "Universe Created by Allah Equation of Hahslm 472319 as Big Bang Concept and Eid Pray Symbols," in 2nd International Conference on Islam, Science and Technology (ICONIST 2019), 2020, pp. 1-4.

[7] B. Hossain, "Islamization of Monetary Policy of 27 OIC Muslim Countries in Asia: The Successes, The Barriers and The Future Directions," Glob. Rev. Islam. Econ. Bus., vol. 7, no. 2, pp. 91-104, 2020.

[8] M. Huda and M. Mutia, "Mengenal matematika dalam perspektif islam," FOKUS J. Kaji. Keislam. Dan Kemasyarakatan, vol. 2, no. 2, p. 182, 2017.

[9] A. R. A. H. Hamid, "Social responsibility of medical journal: a concern for COVID-19 pandemic," Med. J. Indones., vol. 29, no. 1, pp. 1-3, 2020.

[10] Z. A. Bagir, "Islam, science, and 'Islamic science': How to 'integrate'science and religion," Sci. Relig. a post-colonial world. Interfaith Perspect., 2005.

[11] R. M. Aziz, "Islam dan Pengetahuan," Jakarta Esa Alam, 2016.

[12] R. M. Aziz, "Hahslm Theory as Guidance of Straight Path in Management of Hajj and Finance," KnE Soc. Sci., pp. 105-120, 2018. 